\title{
Poética e ritmo da MPB
}

\section{The poetic and rhythm of MPB \\ Poética y ritmo dela MPB}

Este texto reflete as relações do clássico com o popular dentro da cultura nacional, buscando estabelecer um nível de vínculo entre o conceito de música popular brasileira-do maxixe à chamada $M P B$-, com as formas clássicas do verso - da redondilha ao metro alexandrino.
This text reflects the relationship of classical and popular inside of the national culture, seeking to establish a link between the level concept of Brazilian popular music - from maxixe to so called MPB-, with the classic forms of verse - the roundels of the Alexandrian meters.
Este texto refleja las relaciones clásicas con popular dentro de la cultura nacional, tratando de establecer un vínculo entre el concepto de música popular brasileña-maxixe a la 'MPB': con las formas clásicas del verso - da redondilha al metro alejandrino.
Palavras-chave: $M P B$, literatura e música, teorias da literatura, estudos comparatistas.

\section{Autor:}

\section{Prof. Dr. Lucio Valentim}

Doutor em Letras Vernáculas pela UFRJ e professor presencial/ EAD da Universidade Estácio de Sá.

E-mail:alexhsl@uol.com.br

"Antes de tudo, música". Paul Verlaine [1844-1896]

\section{A MPB}

Desde a crítica de Mário de Andrade ${ }^{1}$ à mais recente de Cravo Albin ${ }^{2}$ - passando pelo crivo de Tinhorão ${ }^{3}$ - a expressão música popular brasileira vem sendo deliberadamente empregada. Aqui, para efeito didático, utilizaremos o conceito de MPB que passa a ser veiculado no Brasil por volta dos anos de 1960, decorrente das controvérsias oriundas do clima político da época - e que engloba "um misto de agregado de gêneros musicais com instituição sociocultural"4 .

Forjada na indústria cultural dos grandes Festivais da Canção ${ }^{5}$, ou originária dos CPC's 6 que começavam a proliferar no rastro dos tempos - clima de engajamentos políticos, e de ambiente universitário-classe média -, a epígrafe MPB passa

\footnotetext{
1 Mário de Andrade (1890-1954), um dos idealizadores do movimento modernista brasileiro de 1922, foi poeta, romancista, contista, crítico, musicólogo e professor - o que hoje chamaríamos multimídia.

2 Cravo Albin (1940), crítico musical que dá nome à mais recente publicação em dicionário acerca da Música Popular Brasileira.

3 José Ramos Tinhorão (1928), considerado o mais polêmico e investigativo historiador e crítico musical brasileiro do séc. XX.

4 NAPOLITANO, Marcos. Síncope das Idéias: a questão da tradição na música popular brasileira. [S.1.]: Editora Fundação, Perseru Abramo, 2007.
}

a ter como característica primária o forte teor de contestação político-social, ainda que, conforme se afirmará neste texto, este apelo se tenha perdido ao longo dos séculos.

Contudo, devido à sua incontestável sofisticação poético-musical, juntamente ao auxílio luxuoso da mídia emergente no Brasil à época, a $M P B$ logo cairia no gosto das chamadas elites, formando uma barreira identitária através da qual, paradoxalmente, as classes alta e média do país tentariam se distinguir musical e, por conseguinte, culturalmente do gosto popular.

Para o crítico e músico Luiz Tatit ${ }^{7}$, então, o conceito de $M P B$ hoje deveria soar anacrônico. Se nos anos de chumbo ela pretendeu atuar quase como um partido político $\left(M P B / \mathrm{MDB}^{8}\right)$, exercendo resistência tanto à política de Estado quanto à política do mercado das canções supostamente menos engajadas ou comprometidas (a alienação da Jovem Guarda, o entreguismo Tropicalista, ou o hedonismo da Bossa Nova), agora que incorporou todos os estilos e ritmos (o rock, o baião, o samba, a valsa, a moda, os Beatles \& Rolling Stones), a $M P B$ passou a ser reconhecida genérica e simplesmente como a canção popular dita "de qualidade apurada", feita para um público considerado "mais exigente" do que a média.

Logo, liberta do engajamento político-ideológico, restaria o acabamento estético - ao qual iremos neste texto nos dedicar.

Ainda que caracterizada pelo hibridismo, a mescla e a mistura desde as origens, a nossa música popular logrou escapar

\footnotetext{
5 O Festival Internacional da Canção (FIC) ocorreu de 1966 a 1972, patrocinado pela TV Globo; O Festival de Música Popular Brasileira (FMPB), de 1965 a 1979, teve seis edições, e foi patrocinado por três emissoras distintas ao longo dos tempos: TV Excelsior, TV Record e TV Tupi.

${ }^{6}$ Os Centros Populares de Cultura propunham a resistência política à cultura dita oficial - sobretudo no âmbito do teatro e da música -, das multinacionais, das elites, do imperialismo yankee etc.

${ }^{7}$ TATIT, Luiz. O século da canção. Cotia: Ateliê Editorial, 2004, p. 35.

${ }^{8}$ É bastante evidente a similaridade fônica da sigla com a do Movimento Democrático
} Brasileiro, partido de oposição - consentida - à Ditadura Militar; atual PMDB. 
à simples curiosidade exótica, fugindo daquilo a que Oswald de Andrade ironicamente denominaria "macumba para turista"9. $\mathrm{Ou}$ seja, embora de influências várias e díspares, a $M P B$ manteria certa autenticidade sonora, vocabular e rítmica que a faz identificar - e distinguir - mundo afora, perante outras manifestações musicais populares. Conforme, desde o início do século modernista, já observava Mário de Andrade:

Cabe lembrar mais uma vez aqui do quê é feita a música brasileira. Embora chegada no povo a uma expressão original e étnica, ela provém de fontes estranhas: a ameríndia em porcentagem pequena; a africana em porcentagem bem maior; a portuguesa em porcentagem vasta. Além disso a influência espanhola (...) A influência européia também, não só e principalmente pelas danças (valsa, polca, mazurca, shottsh) como na formação da modinha. (...) Isso continuou até bem tarde como demostram certas peças populares de Carlos Gomes e principalmente Francisca Gonzaga.

A nossa musicalidade, portanto, de gênese ibero-barroca, vem ao longo dos tempos, antropofagicamente, alimentando-se pelo caminho do fino biscoito ocidental - quer seja o lirismo romântico, o formalismo parnasiano, ou a musicalidade simbolista -, para fundir poesia à métrica e à música. Nasce daí a variedade de ritmos populares que, necessariamente, irão desembocar no primeiro açude da $M P B$. Na conclusão de Mário:

Se fosse nacional só o que é ameríndio, também os italianos não podiam empregar o órgão que é egípcio, o violino que é árabe, o cantochão que é grecoebraico, a polifonia que é nórdica, anglo-saxônica flamenga e o diabo. Os franceses não podiam usar a ópera que é italiana e muito menos a forma-de-sonata que é alemã. E como todos os povos da Europa são produto de migrações pré-históricas se concluiria que não existe arte européia. ${ }^{11}$

No tocante especificamente ao metro e à lira, o mestre Antônio Candido também já apontava, por exemplo, na poesia neoclássica de Silva Alvarenga 12 a verve de uma "poesia lírica em metro fácil e cantante, de sabor quase popular" e que "já toca o ponto onde a poesia se desfaz em música 13". Desta maneira, a despeito da suposta abolição da métrica, instaurada pelo modernismo de $1922^{14}$, a poética da canção manteria a sua medida, desde remotos tempos colonizatórios - fundadores do imaginário musical da nação brasileira.

No ensaio espertamente chamado Machado Maxixe: $o$ caso Pestana, José Miguel Wisnik ${ }^{\mathbf{1 5}}$, fazendo um estudo dos dois ritmos que dariam origem ao popular maxixe - a polca europeia e a música dos escravos, o lundu -, acaba por demonstrar que o encontro do salão (polca) com o fundo de quintal (lundu) vai conferir, naquele instante histórico, um toque brasileiro aos gêneros europeu e africano, constituindo-se na base do primeiro ritmo popular urbano no Brasil.

\footnotetext{
${ }^{9}$ Oswald de Andrade, no Manifesto da Poesia Pau-Brasil (1924), critica o que chamou "macumba para turista", isto é: a produção cultural nacional feita de encomenda, para agradar o estrangeiro.

${ }^{10}$ ANDRADE, Mário de. Ensaio sobre a música brasileira. $3^{\mathrm{a}}$ ed. São Paulo: Vila Rica; Brasília: INL, 1972, p. 03.

11 Idem.

12 Manuel Inácio da Silva Alvarenga (1749 - 1814), poeta árcade brasileiro.

${ }^{13}$ CÂNDIDO, Antonio. Formação da literatura brasileira (momentos decisivos). 4. ${ }^{\text {a }}$, São Paulo: Martins, s.d. v. 1, p. 142.

14 É sabido que, anti-parnasiano por vocação, o movimento modernista de 1922 propôs a ruptura com a forma fixa, numa investida direta à métrica - privilégio dos parnasianos -, instaurando como modelo o verso livre.

15 WISNIK, José Miguel. -Machado maxixe. O caso Pestana.- In Teresa, n 4/5. São Paulo: Editora 34, 2003. p. 13-79.
}

Desta maneira, o conto Um homem célebre ${ }^{16}$, ao qual faz referência o texto de Wisnik, além de servir para atestar a sagacidade e a modernidade machadianas, ainda vale como estudo para compreender o misto entre popular e erudito que teria implicações definitivas na formação do conceito de cultura urbana e, por conseguinte, na transformação da moderna música popular brasileira - a tal $M P B$.

\section{A medida da $M P B$}

O sucesso da redondilha junto à audição popular é conhecido desde a Idade média, onde foi sistematicamente utilizada pelos poetas do Cancioneiro Geral, de Garcia de Resende ${ }^{17}$, por exemplo; e depois por Camões - já nos inícios do Renascimento. Mas a denominação só foi dada àqueles versos de cinco ou sete sílabas, antes conhecidos como medida velha, a partir do século XVI - desde então batizados redondilha menor e redondilha maior. $\mathrm{O}$ termo redondilha, derivado do termo latino rotundus, via o ibérico redondilla, resultaria no diminutivo português redondinha. Isto é: um verso conciso, delgado e que "desce redondo".

Hoje entendemos melhor porque as cantigas, para ficarem "redondinhas", eram compostas nessa modalidade de versos: a facilidade de absorção auditiva figura como fator preponderante.

Assim como a vasta cultura nordestina - herdeira direta da cultura do medievo - a nossa canção popular urbana não cansa de lançar mão desta herança literária da métrica. Aliás, a essência mesma da $M P B$ desponta desse encontro entre letra e melodia, que, aproveitando do caráter vocálico e musical da língua portuguesa, utiliza a técnica do metro para dar liberdade e ritmo à letra-poesia.

É, portanto, a métrica quem confere ritmo à construção de sentido da canção poética. Eventualmente ocorre - sobretudo em música popular - de o ritmo se fixar no inconsciente mais que a palavra cantada, e a poesia da letra quedar escondida na música, na melodia e no ritmo das canções. Tal fenômeno se dá tanto com a canção em língua estrangeira, que prescinde de compreensão prévia do ouvinte/receptor na decifração dos versos para a fruição apaixonada do som, da melodia; mas também com a própria canção popular em língua nacional que - pela massificação auditiva - é fixada em melodia e ritmo no imaginário coletivo, sem que necessariamente se tome conta do teor poético que a envolve18.

Neste aspecto reiteram-se as palavras de Augusto de Campos, para quem " a palavra cantada não é a palavra falada, nem a palavra escrita. A altura, a intensidade, a duração, a posição da palavra no espaço musical, a voz, mudam tudo. A palavra-canto é outra coisa"19.

16 Conto tipicamente machadiano, publicado como folhetim no periódico "A Estação", em 1883 e, posteriormente, no livro Várias Histórias, em 1896, relata a frustração de um compositor popular de polcas cujo maior desejo era criar obras clássicas.

${ }^{17}$ Garcia de Resende reuniu e fez imprimir, em 1516, uma compilação castelhana datada de 1511, denominada Cancioneiro Geral, cujo conteúdo seria a poesia produzida nas cortes dos reis D. Manuel I, D. Afonso V, D. João II. O uso dos metros e gêneros castelhanos, tais quais o verso em redondilha, com o mote e volta foram também difundidos ali.

18 Por exemplo, a letra cifrada de Vaca profana, http://www.youtube.com/ watch? $\mathrm{v}=\mathrm{MjCkYMVrGxU}$, de Caetano Veloso, pode ter passado impune pela maioria dos receptores/ouvintes, mas sua melodia rock certamente não.

${ }^{19}$ CAMPOS, Augusto. Balanço da bossa e outras bossas. São Paulo: Perspectiva, 1974, p. 182 . 
Então, pressupondo ser o verso cada frase melódica emitida pela voz, numa sequência rítmica regular, com início e pausa ao final, temos que a histórica Pelo telefone ${ }^{20}$ (Donga/ Mauro de Almeida), considerada a primeira gravação fonográfica de música popular no Brasil21, já é meio redondilhada, levando-se, sobretudo, em conta a natureza iâmbica ${ }^{22}$ dos versos $1^{\circ}$ e $4^{\circ}$ (com pé formado por uma sílaba átona e uma tônica), o que faz da estrofe inicial do samba-baião-maxixe um conjunto de redondilhas menores:
(O) chefe da polícia [5]
Pelo telefone [5]
Mandou me avisar [5]
(Que) lá na carioca [5]
Tem uma roleta [5]
Para se jogar [5]

A canção-homenagem de Gilberto Gil, Pela internet ${ }^{23}$, consegue atualizar o conteúdo do samba de Donga (o jogo agora é informatizado e o aviso chega pela rede, em websites etc), mas a forma da cantiga cibernética é também a redondilha, mantendo, inclusive, o mesmo esquema de tônicas/átonas da canção original.

No rastro do samba, Garota de Ipanema ${ }^{24}$, clássico da Bossa Nova, nos introduz em forma de redondilhas no ritmo malemolente da coisa de Ipanema:

Olha que coisa mais linda[7]

Mais cheia de graça [5]

É ela menina[5]

Que vem e que passa [5]

No doce balanço[5]

caminho do mar[5]

Na contramão do étimo tupi de ipanema - rio sem peixe -, o que à primeira vista o eu-poético - este flanêur tupiniquim - vislumbra é um "peixão" em forma de mulher ao sol: garota-menina-moça, que passa na cadência rotunda da redondilha: uma maior, cinco menores. Seguindo o mesmo ritmo, na estrofe seguinte a similaridade da rima também se completa e mantém: linda-menina e graça-passa, na $1^{\mathrm{a}}$ estrofe; dourado-balançado e Ipanema-poema, na $2^{\mathrm{a}}$ estrofe - fazendo o passar da segunda ainda se encontrar com o mar que finaliza a primeira.

Essa precisão da forma parece mesmo dar sustento ao sincopado da bossa-moça:
Moça do corpo dourado[7]
Do sol de Ipanema [5]
$O$ seu balançado[5]
é mais que um poema[5]
É a coisa mais linda[5]
que eu já vi passar [5]

Vale lembrar aqui, aliás, a letra original de Vinícius que, sob o título Menina que passa ${ }^{25}$, tanto desagradou ao parceiro Tom Jobim, que não chegou ao conhecimento do grande público:

\footnotetext{
${ }^{20}$ Link para o vídeo: http://letras.terra.com.br/donga/1120957/

21 Tinhorão já argumentara - com provas - não ser esta a primeira gravação fonográfica brasileira.

${ }^{22}$ Estes versos são do tipo pentâmetro iâmbico: têm 5 pés (sílabas), na sequência átona - tônica.

${ }^{23}$ Link para o vídeo: $h$ ttp://www.youtube.com/watch?v=WM6_DE01BFE

${ }^{24}$ Link para o vídeo: http://letras.terra.com.br/tom-jobim/20018/

${ }^{25} \mathrm{O}$ título desta versão faz lembrar o famoso Soneto da mulher que passa: Meu Deus, eu quero a mulher que passa! /Eu quero-a agora, sem mais demora/
}

Vinha cansado de tudo

De tantos caminhos

Tão sem poesia

Tão sem passarinhos

Com medo da vida

Com medo de amar

Quando na tarde vazia

Tão linda no espaço

Eu vi a menina

Que vinha num passo

Cheio de balanço

Caminho do mar

Esta versão inicial não apresentaria outra tangência com a famosa senão o compasso da redondilha - no qual a menina passa. Não bastasse a experiência poética visivelmente inferior, a versão traz ainda clima negativo a circundar o eu que trafega reflexivo, sorumbático e medroso da vida, bem distinto do flanêur zona sul que canta a garota passante de Ipanema.

Aqui, a menina representa quase uma epifania, enquanto que na clássica versão, ao contrário - mais solar -, faz de cara resplandecer ao sol a coisinha a passar.

Porém, a despeito do cenário Zona Sul26, praia, sol e bar decantado nas estrofes inicias, o que subjaz no refrão em ambas as versões é o temário da solidão a dois: a solidão do eu que solitário canta a beleza que passa; e da própria beleza garota-menina-moça que também passa - sozinha:
Ah, porque estou tão sozinho[7]
Ah, porque tudo é tão triste[7]
Ah, a beleza que existe[7]
A beleza que não é só minha[9]
Que também passa sozinha[7]

A linha melódica desta estrofe-refrão, inclusive, a distingue, das estrofes iniciais: já não vem redondinha, porque plena de lamentações. Numa perguntação gradativamente irônica ${ }^{27}$, o eu que canta parece aqui encontrar consolo na solidão do outro que, por sua vez, passa também totalmente alheio àquele que o vê - e canta:

Ah, se ela soubesse[6]

Que quando ela passa[5]

O mundo inteirinho [5]

se enche de graça[5]

E fica mais lindo[5]

Por causa do amor [5]

E muito embora, ao final, o amor seja reivindicado como o redentor de tudo, à luz do sol, parece ser ao velho temário da carência e da falta - já cantado por nossos ancestrais ibéricos - que essa Bossa novamente remete, revelando a efemeridade das coisas da vida que, efetivamente, passam.

Djavan, em Faltando um pedaço ${ }^{28}$, constrói seus versos em redondilhas perfeitas $-\mathrm{e}$ maiores:

A minha amada mulher que passa!/ Que fica e passa, que pacífica,/ Que é tanto pura como devassa ()

${ }^{26} \mathrm{Na}$ crítica de Tinhorão, a Bossa Nova, reiterando o cenário Zona Sul - praia, sol, cerveja, garotas -, claramente idealizava uma determinada classe social e seu gosto, num processo ideológico-musical alienado/alienante em relação ao contexto de ditadura militar.

${ }^{27}$ Usa-se aqui o conceito de ironia no sentido socrático: uma pergunta reduzida, sem interrogações e sem carência de respostas.

${ }^{28}$ Link para o vídeo: http://www.youtube.com/watch?v=TZPXCF4qYNk\& feature=related 


\section{O amor é um grande laço}

Um passo pruma armadilha

Um lobo correndo em círculo

Pra alimentar a matilha

Destaca-se de início este aspecto frequente na poética da música popular: a licença. Muito embora todos saibamos que o coletivo de lobo não seja matilha, o poeta inicia por impetrar um mandato de licença poética e conferir aos lobos o coletivo que pertence na verdade aos cães, apenas para não perder a sequência de ilha e filha e que, junto com armadilha, comporiam o feixe rímico das duas primeiras estrofes:

Comparo sua chegada

Com a fuga de uma ilha

Tanto engorda, quanto mata

Feito desgosto de filha

Nestas estrofes iniciais, o tal pedaço que falta ao amor desde o título, ao longo dos versos, vai-se redondilhando, numa sucessão de metáforas e comparações, onde prevalecem em formas substantivas as equivalências do amor: laço, passo-armadilha, lobo, fuga, desgosto. E, mais ainda, no início da estrofe seguinte: raio galopante.

$O$ amor é como um raio

galopando em desafio

Abre fendas cobre vales,

revolta as águas dos rios

Mas, enquanto na $1^{\mathrm{a}}$ quadra se enfatiza a figura da $m e$ táfora, posto que o poeta afirma ser o amor um laço, um passo, um lobo - imagens tanto cíclicas quanto sinistras do amor - a partir da $2^{\mathrm{a}}$ quadra, se considerarmos a canção um conjunto de seis quartetos, o poeta ameniza e doura a pílula do amor na figura da comparação. A partir de então o amor não é, mas soa como se fosse.

Nestes versos comparativos parecem residir as imagens mais enigmáticas e escatológicas da canção, pois ao mesmo tempo em que revelam um amor capaz de criar profundos acidentes geológicos - graves feridas na natureza, ondas, tsunâmis, fendas imensas -, também o fazem comparar à imagética de amarguras menores: as do limão ou as do espinho. Ainda assim, o ambiente descrito é o cenário pérfido da solidão:

Quem tentar seguir seu rastro

se perderá no caminho

Na pureza de um limão

ou na solidão do espinho

Ou seja: esse amor djavanicamente agônico revela-se minguado e, conseguintemente, também se investe da rigidez da forma para revelar a carga sêmica da falta:

$O$ amor e a agonia

cerraram fogo no espaço

Brigando horas a fio,

o cio vence o cansaço

Enfim, esta canção de amor, no fundo, refere na verdade uma vez mais à semântica despedaçada da solidão a dois:

E o coração de que ama

fica faltando um pedaço

Que nem a lua minguando, que nem o meu nos seus braços
Dentro da chamada vertente "sertaneja" brasileira - cuja variada complexidade parte de Alvarenga e Ranchinho ${ }^{29}$, passa pelo rock rural de Sá e Guarabyra ${ }^{30}$ e chega aos limites de Zezé de Camargo e Luciano e similares ${ }^{31}$ - a figura do cantador Elomar ${ }^{32}$ representa uma de suas expressões mais solitárias e sofisticadas. Sobre ele afirmou Vinícius de Moraes:

"uma sábia mistura do romanceiro medieval, tal como era praticado pelos reis-cavalheiros e menestréis errantes e que culminou na época de Elizabeth, da Inglaterra; e do cancioneiro do Nordeste, com suas toadas em terças plangentes e suas canções de cordel, que trazem logo à mente os brancos e planos caminhos desolados do sertão, no fim extremo dos quais reponta de repente um cego cantador com os olhos comidos de glaucoma e guiado por um menino - anjo a cantar façanhas de antigos cangaceiros ou "causos" escabrosos de paixões espúrias sob o sol assassino do agreste. ${ }^{33 \text { ", }}$

Desta sorte, sendo o nosso cantador mais próximo do romanceiro medieval, Elomar, em $\boldsymbol{O}$ pedido ${ }^{34}$, realiza uma atípica - porque moderna - cantiga de amigo,

Já que tu vai lá pra fêra

traga de lá para mim

Água da fulô que chêra,

Um novelo e um carrim

que, enquanto típica canção do campo, da cidadezinha, pede vênia para fazer uso irrestrito da linguagem dialetal, falada/cantada aqui transcrita de ouvido -, a conferir certa autenticidade à voz que emite o som que canta:

Traz um pacote de miss

Meu amigo Ah! Se tu visse

Aquele cego cantadô

Um dia ele me disse

Jogando um mote de amô

Que eu havera de viver

Por este mundo e morrer

Ainda em flô

O tema cantado - conforme observara Vinícius -, pleno de cordéis, caminhos desolados do sertão, cegos videntes cantadores e paixões espúrias se encaixa perfeitamente à forma da redondilha maior, tipo de verso que compõe a base rítmica da cantiga de Elomar:

Passa naquela barraca

Daquela mulé reisêra

Onde almoçamo paca,

Panelada e frigidêra

29 Popular e pioneira dupla sertaneja brasileira, formada em 1929 por Murilo Alvarenga (1911 - 1978) e Diésis dos Anjos Gaia, o Ranchinho (1912 - 1991).

${ }^{30}$ Luíz Carlos Pereira de Sá (1945) e Guttemberg Nery Guarabyra Filho (1947). Eram artistas solo até formarem, juntamente com Zé Rodrix - José Rodrigues Trindade (1947-2009), que antes era do grupo Som Imaginário - , a banda de rock rural, Sá, Rodrix \& Guarabyra, que alcançou sucesso a partir de 1971.

${ }^{31}$ Dupla sertaneja brasileira formada pelos irmãos Mirosmar José de Camargo, o Zezé di Camargo, e Welson David de Camargo, o Luciano. Lançaram o $1^{\circ}$ sucesso, É o amor, em 1991.

${ }^{32} \mathrm{Na}$ definição do dicionário Cravo Albin: "Com seu canto, inspirado no falar sertanejo e com sua construção musical inspirada na tradição trovadoresca da Idade Média, é também apontado, por seus admiradores como menestrel. (...) Seus discos são considerados referência da música regional".

33 Texto do poeta Vinícius de Moraes, para a contracapa do LP "Elomar...das barrancas do Rio Gavião", de 1973.

${ }^{34}$ Link para o vídeo: http://www.cifras.com.br/cifra/elomar/o-pedido 
Inté 'ocê disse uma loa

Gabando a bóia boa

Que das casa da cidade

Aquela era a primêra

Aos poucos o eu-lírico, revelando o universo onde transita, vai discorrendo sobre todas as coisas e personagens que caracterizam o seu restrito mundo. A feira representa o mundo externo, do outro, pleno de novidades breves. E o pedido permanece:

Traz pra mim vãs brevidade

Que eu quero matá a sôdade

Faz tempo que fui na fêra

Ai sôdade...

Neste cenário repleto de quermesses e feitiçarias, onde haverá sempre uma lua cheia, sob a qual um lobisomem deverá passear seus místicos poderes, uma vez mais o sagrado e o profano aparecem, num mesclado característico ao habitat do poeta cantador. Tudo isto dentro da lógica da culpa e do perdão barrocos e sua retórica misteriosa de antíteses:

Ah! Pois sim, vê se num esquece

D'inda nessa lua chêa

Nós vai brincá na quermesse

Lá no riacho d'arêa

Na casa daquele hôme,

Feiticêro curadô

Que o dia intêro é hôme

Filho de Nosso Sinhô

Mas dispois da meia noite

É lobisôme cumedô

Dos pagão que as mãe esqueceu

Do Batismo salvadô

A epifania que demarca o estilo da cantiga se dá quando, na estrofe final, a voz que canta revela um eu-lírico feminino - a moça do campo, da aldeia - que, presa de seu próprio destino, pede/ordena saudosa ao amigo que lhe traga uns regalos da cidade, a fim de tornar-se a mais bonita dentre as flores - ainda que em terra de cego:

Ah! Pois sim vê se num esquece

De trazê ruge e carmim

Ah! Se o dinheiro desse

Eu queria um trancelim

E mais três metros de chita

Que é pra eu fazê um vestido

E ficar bem mais bonita

Que Madô de Juca Dido,

Zefa de Nhô Joaquim

Ao mesmo tempo em que circunscrita ao aspecto formal da redondilha, a canção de Elomar destoa dos motes que envolviam o cantar de amigo tradicional.

Se, na visão de António J. Saraiva, em sua História da Literatura Portuguesa ${ }^{35}$, pode-se "classificar as cantigas de amigo, de acordo com os temários tais quais das bailadas ou bailias, das romaria, marinhas ou barcarolas, (...) das cantigas de fonte, de cenas venatórias, de amiga e mãe, de amiga ou amigas (às vezes ditas irmanas), de despedida, etc.", sempre numa perspectiva de inferioridade emocional da mulher em relação ao sexo oposto, em $\boldsymbol{O}$ pedido a temática é inusitada,

$\overline{{ }^{35} \text { SARAIVA, Antonio José. História da Literatura Portuguesa. Porto Editora, p. } 64 .}$ porque aqui a moça pede sem súplica a um amigo que parte - e que volta. Trata-se, portanto, não de uma cantiga de lamentações ou tristes despedidas de amores incompreendidos, mas antes de uma espécie de anti-cantiga de amigo, onde o que prevalece na forma do pedido-quase-ordem é a autoafirmação da moça na exposição lírica de suas vontades feminis:

Já que tu vai lá pra fêra

Meu amigo, traz essas coisinha

Para mim.

Por sua diversidade rítmica e sua variação tonal, o decassílabo recebe múltipla classificação, em função mesmo das posições das sílabas tônicas que lhe determinam o ritmo. No texto d'Os Lusíadas, por exemplo, Camões já se fartara dos heróicos:

As armas e os barões assinalados $[2,6,10]$

(...) por motivo de guerra reforçados; $[3,6,10]$

Na sequência das medidas clássicas, reparemos que a ousada $M P B$ também se valeu dessa complexa forma do verso, a fim de expressar suas emoções.

A canção Livros $^{36}$, de Caetano Veloso, dentro de uma perspectiva intertextual, aproveita-se do mote do popular Chão de estrelas ${ }^{37}$, de Orestes Barbosa e Silvio Caldas,

Tu pisavas os astros, distraída,

Sem saber que a ventura desta vida

É a cabrocha, o luar e o violão

para, também, em perfeitos decassílabos, construir esta tão clássica quanto sofisticada amostra de $M P B$ :

Tropeçavas nos astros desastrada [3, 6, 10]

Quase não tínhamos livros em casa

E a cidade não tinha livraria

Mas os livros que em nossa vida entraram

São como a radiação de um corpo negro

Destaque-se que, com esta espécie de decassílabo - variação do heróico, fixando a primeira tônica na sílaba $3^{\mathrm{a}}$ ao invés da $2^{\mathrm{a}}$-, Livros literalmente alude, na forma e no nome-objeto, ao clássico-popular momumento da língua portuguesa, eregido por Camões, Os Lusíadas. Em contrapartida, ao variar dentro da tônica camoniana, enfatizando o decassílabo 3, 610 - mais conhecido como martelo agalopado -, Caetano adequa a clássica forma às características intrínsicas da popular canção que canta - uma espécie de marcha-maracatu moderna:

Apontando pra a expansão do Universo

Porque a frase, o conceito, o enredo, o verso

( $E$, sem dúvida, sobretudo o verso)

É o que pode lançar mundos no mundo.

Numa breve aproximação entre os ambientes lírico-poéticos das duas canções, ressaltam as diferenças sociais que envolvem os eu-líricos. Enquanto no Chão de estrelas o eu lírico lamenta, rimada e linearmente - com início, meio e fim -, o palco iluminado que era sua vida antes do evento que culmina na desilusão amorosa, a canção de Caetano nos apresenta - in media res e abolindo rimas - um universo lírico complexo, onde a relação eu-outro tem de permeio o objeto livro, metáfora-título da canção:

\footnotetext{
${ }^{36}$ Link para o vídeo: http://www.youtube.com/watch?v=7vV22LRNrpk

${ }^{37}$ Link para o vídeo: http://www.youtube.com/watch?v=wvSsOpA7jm4
} 


\section{Tropeçavas nos astros desastrada}

Sem saber que a ventura e a desventura

Dessa estrada que vai do nada ao nada

São livros e o luar contra a cultura.

A canção de Orestes Barbosa não apenas canta o "palco iluminado" da pobreza - afinal esse chão está poeticamente estrelado do reflexo das estrelas que transpassam o teto do barracão de zinco, sem telhado -, mas também liricamente enfatiza o velho discurso da conformidade, difundido no senso comum, sobretudo, pelo Naturalismo literário ${ }^{38}$, de que a despeito da penúria material, da miséria e da exclusão se pode encontrar a felicidade, bastam "a cabrocha, o luar e o violão"39.

Mas, e os Livros:

Os livros são objetos transcendentes

Mas podemos amá-los do amor táctil

Que votamos aos maços de cigarro

Domá-los, cultivá-los em aquários,

Já pelo próprio objeto-fetiche da canção de Caetano - o livro - percebe-se a distinção de classe entre um ambiente poético e o outro. Se no Chão de estrelas o que ilumina é a lua, no universo lírico caetaneado, os livros são objetos transcendentes e que iluminam, inclusive, o amor cantado. A canção de Caetano, desta forma, consegue conferir maior carga poética aos livros do que a canção que a inspirou conferiria à própria lua:

Em estantes, gaiolas, em fogueiras

Ou lançá-los pra fora das janelas

(Talvez isso nos livre de lançarmo-nos)

Ou o que é muito pior por odiarmo-los

Podemos simplesmente escrever um

Composto em decassílabos viscerais, o universo letrado de Livros, portanto, representa a metáfora subversiva da luz o luar da razão -, a redimir o homem do limbo do nada, quer dizer: da aniquilação da morte:

Encher de vãs palavras muitas páginas

E de mais confusão as prateleiras.

Tropeçavas nos astros desastrada

Mas pra mim foste a estrela entre as estrelas

E, concluindo com o que afirma a cantiga:

"(E, sem dúvida, sobretudo o verso)

É que pode lançar mundos no mundo",

o poeta parece corroborar com o insigth que originou este ensaio - a crença no irrevogável poder transformador da palavra poética cantada.

Seguindo a perspectiva da metáfora social, Gilberto Gil em $\boldsymbol{A}$ novidade ${ }^{\mathbf{4 0}}$, na forma de decassílabos raros, também chamados pentâmetro iâmbico - um misto do heróico e do

\footnotetext{
36 Link para o vídeo: http:/www.youtube.com/watch?v=7vV22LRNrpk

${ }^{37}$ Link para o vídeo: http://www.youtube.com/watch?v=wvSsOpA7jm4

38 Baseado numa visão filosófica, segundo a qual o mundo somente pode ser explicado pelas leis da natureza; e de que o homem está inevitavelmente sujeito e condicionado ao biológico - o que lhe determinaria o social -, o Naturalismo, pioneiramente, retratou cenas felizes de ambientes pobres, quer seja no campo, na fábrica ou na vida social.

${ }^{39}$ As festas ocorridas n'O cortiço, clássico de Aluízio Azevedo (1857-1913) servem para exemplificar esta afirmativa.

${ }^{40}$ Link para o vídeo: http://letras.terra.com.br/gilberto-gil/46179/
}

sáfico -, realiza a proeza melódica de fazer tônicas todas as sílabas pares do verso:

A novidade veio dar à praia
Na qualidade rara de sereia
Metade o busto d'uma deusa Maia
Metade um grande rabo de baleia

A novidade mesmo é conseguir que esta forma clássica dê sustento ao ritmo do reggae, compondo uma das mais belas canções populares de temática sociocultural, de diferença de classes: enquanto o esfomeado - figura metáfora do homem comum, excluído pela ignorância, vê na novidade apenas um peixe, para lhe saciar a carência da fome física, o poeta, visto enquanto aquele que consegue enxergar para além da fome material, reivindica a transcendência da compreensão para além do estômago, aspirando ao sonho profundo, esotérico e transcendental - que lhe pertence - para além da média do senso comum.

Contudo, o reggae heroico-sáfico, em sua forma, serviu como luva para conter a estória da sereia cantada somente até o instante em que a novidade começa a virar paradoxo. E depois, guerra. Dali em diante, os versos tornar-se-iam tão irregulares quanto os episódios que cantam:
A novidade era o máximo[7]
Do paradoxo[4]
Estendido na areia[[6]
Alguns a desejar[6]
Seus beijos de deusa [5]
Outros a desejar[6]
Seu rabo prá ceia...[5]

No refrão, reforça-se a intenção de denúncia da canção, quando o que se reflete é o paradoxo do mundo, contido na desigualdade material e cultural reincidente entre os humanos:

Oh! Mundo tão desigual

Tudo é tão desigual

$\hat{O} \hat{O} \hat{O} \hat{O} \hat{O} \hat{O} \hat{O}$ !

Oh! De um lado esse carnaval

De outro a fome total

ÔÔOÔỐÔOÔ!

Sendo um reggae, a canção de imediato remeteria talvez a realidades faveladas, negras e pobres (Alagados, Trenchtown, Favela da Maré), mas o poeta, transferindo a cena para a beira da praia, deu vez ao ambiente rude da pesca - também iletrado -, ao mesmo tempo em que circunscreve seus personagens ao mitológico e poético cenário do mar. Dois observadores, um só objeto. Duas visões de mundo:

E a novidade que seria um sonho

O milagre risonho da sereia

Virava um pesadelo tão medonho

Ali naquela praia, ali na areia...

Da diferença de classe nasce a discórdia da guerra: eis a cruel novidade que faz fútil o sonho dos homens. Mais ainda, para além da leitura social, na cantiga de Gil misturam-se também o sagrado e o profano, uma vez que na figura da sereia - parte mulher, parte peixe -, eros também passeia.

Assim, quer seja da fome estomacal quer seja da fome sexual, em A novidade todas as necessidades do corpo encontram-se, em conflito, explodindo:

A novidade era a guerra[7]

Entre ofeliz poeta[6] 


\author{
E o esfomeado[4] \\ Estraçalhando[4] \\ Uma sereia bonita[7] \\ Despedaçando [4] \\ o sonho pra cada lado[7]
}

Embora todo alexandrino seja um dodecassílabo, nem todo verso de 12 sílabas é um alexandrino. Sobretudo porque a modalidade alexandrina exige precisão nas duas tônicas - a $2^{\mathrm{a}}$ e a $4^{\mathrm{a}}$. Portanto, de ritmo mais solto em relação ao alexandrino clássico, e mesmo por sua natureza alternativa, o verso dodecasílabo parece ajustar-se melhor à síncope da popular música brasileira.

Vejamos que, em Anunciação ${ }^{\mathbf{4 1}}$, esta é a forma com que Alceu Valença nos apresenta o ambiente tanto escatológico, quanto profético e libidinoso que prepara a aparição deste ente-tu vindouro, a quem o eu-poético espera. Meio sagrado, meio profano, o clima geral da canção uma vez mais reivindica, na moderna $M P B$, raízes ibéricas presentes na poesia místico-religiosa ${ }^{\mathbf{4 2}}$.

Aludindo a metáforas e símbolos do mito cristão, esta modalidade poética, em busca da transcendência, é pautada por uma expressão sensual do amor ao ser divino. E este desejo desce da alma rumo ao corpo, numa vontade intensa de união com o sagrado, atingindo uma espécie de êxtase místico.

Neste processo de antropoformização, conforme se vê nos versos da canção, a lírica amorosa faz revelar um misto de eroticidade e santidade, ao cantar a estória de um eu que espera um outro, embalado pela bruma das mais profundas paixões,:

Na bruma leve das paixões que vêm de dentro

Tu vens chegando pra brincar no meu quintal

Adotada pelo barroco, essa vertente tornar-se-ia corriqueira na produção lírica de Gregório de Matos, por exemplo, na mescla do sagrado com o profano, de fé com sensualidade.

Então, em versos trímeros, assim chamados por possuírem pés tripeônicos de quarta, ou 3 acentos tônicos, nas $4^{\mathrm{a}}, 8^{\mathrm{a}}$ e $12^{\mathrm{a}}$ sílabas - alternados de $4 \mathrm{em} 4$ - o ritmo anunciado parece mesmo cavalgar a sílaba à luz sol, cobrindo de sensualidade a imagem poética. Nesta perspectiva, o erotismo do texto de Alceu é latente.

$\mathrm{O}$ anjo pernambucano, seguindo o modelo do anjo bíblico ${ }^{43}$, também porta o anúncio de uma ambigua paixão; mas enquanto a bíblica é filial; a paixão que vem de dentro de Alceu, iconoclasta, é física, carnal. E através do ambiente semântico de sinos, domingos, catedrais, sinais - mesclados a sussurros ao ouvido -, este anjo parece querer mais esconder do que revelar a verdadeira identidade, e os reais propósitos, da figura que vem chegando, com o peito nu e os cabelos ao vento:

No teu cavalo peito $\mathrm{nu}$, cabelo ao vento

E o sol quarando nossas roupas no varal

Na sequência, o refrão visionário misticamente retumba a verdade da profecia evocada nos versos. E para este efeito variando o critério rítmico - o poeta faz jus soar este dodecassílabo muito distinto, com tônica em todas as sílabas pares que, sendo seis, nos permite chamá-lo hexâmetro iâmbico ${ }^{44}$, a alternar átona-tônica - como o badalar mesmo de sinos:

\footnotetext{
$\overline{41}$ Link para o vídeo: http://www.youtube.com/watch?v=Ud8w9PFT19c\&feature=related

42 Refiro-me aqui, sobretudo, à produção erótico-religiosa dos carmelitas espanhóis Santa Teresa de Ávila (1515-1582) e São João de la Cruz (1542-1591).

${ }^{43} \mathrm{Na}$ Anunciação cristã, o Arcanjo Gabriel avisa a Maria que, apesar da virgindade, milagrosamente conceberia uma criança, que seria o Filho de Deus.

44 Uma corruptela do decassílabo tipo pentâmetro iâmbico - misto de sáfico e heroico -, que traz tônicas todas as sílabas pares do verso.
}

Tu vens, tu vens, eu já escuto os teus sinais

Tu vens, tu vens, eu já escuto os teus sinais

Enfim, esta variação dentro da métrica dos dodesassílabos parece ter servido bem ao propósito erótico agalopado do xote de Alceu,

A voz do anjo sussurrou no meu ouvido
Eu não duvido, já escuto os teus sinais
Que tu virias numa manhã de domingo
Eu te anuncio nos sinos das catedrais...

porque, como o poeta já revelara macunaimicamente ${ }^{45}$ desde o início do texto, os dois da canção - apadrinhados pelo anjo -, vão mesmo é brincar nus no quintal.

\section{Por uma conclusão}

Para este texto - cheio de exemplos esparsos -, foram eleitos, aleatoriamente, seis clássicos de distintas épocas e estilos da MPB: Garota de Ipanema, Faltando um pedaço, $O$ pedido, Livros, A novidade, Anunciação. Porém, propositalmente, três formas poéticas com níveis de dificuldades bastante distintos dentro da lógica da medida poética também foram contemplados: 3 redondilhas, duas menores e uma maior, 2 decassílabos e 1 dodecassílabo - na ordem respectiva em que aparecem as canções.

Uma infinidade de outros exemplos de canções metricamente perfeitas com as quais a música popular teceu suas rimas ao longo dos séculos XX e XXI poderiam aqui ter sido citados: o media res redondilhado no verso primeiro do Onde anda você, o martelo agalopado de $\boldsymbol{O}$ quereres ${ }^{47}$, os raríssimos hendecassílabos de $\boldsymbol{O}$ ciúm $^{\mathbf{4 8}}$ - apelidados também galope à beira mar -, ou o arredondado das velas do Mucuripe ${ }^{49}$ de Fagner, ou do compasso da $\boldsymbol{A} \boldsymbol{B a n d a}^{50}$ de Chico etc.: todos a confirmar que o metro clássico esteve sempre presente, dando auxílio luxuoso à variação linguística dos ritmos que compõem a moderna $M P B$. Referências bibliográficas

\footnotetext{
$\overline{45}$ Referência à Macunaíma, personagem clássico de Mário de Andrade, que usava o termo brincar no sentido de fazer sexo.

${ }^{46}$ Link para o vídeo: http://www.youtube.com/watch?v=E2OG1hqjw9c

${ }^{47}$ Link para o vídeo: http://www.youtube.com/watch?v=Njjeb2bN578

${ }^{48}$ Link para o vídeo: http://letras.terra.com.br/caetano-veloso/44755/

${ }^{49}$ Link para o vídeo: $h t t p: / / w w w . y o u t u b e . c o m / w a t c h ? v=m W t b 8 C Q 3 C e o \& f e a t u r e=f v w r e l$

${ }^{50}$ Link para o vídeo: http://www.youtube.com/watch?v=wFPPawLq 5Q
} 
1. ANDRADE, Mário de. Ensaio sobre a música brasileira. $3^{\mathrm{a}}$ ed. São Paulo: Vila Rica; Brasília: INL, 1972.

2. CAMPOS, Augusto de. Balanço da bossa e outras bossas. São Paulo: Perspectiva, 1974.

3. CÂNDIDO, Antonio. Formação da literatura brasileira (momentos decisivos). 4. ${ }^{\text {, }}$, São Paulo: Martins, s.d. v. 1

4. CASTRO, Ruy. Chega de saudade. São Paulo: Companhia das Letras, 1990.

5. FAVARETTO, Celso. Tropicália: alegoria, alegria. São Paulo: Kairós, 1979.

6. HOLLANDA, Heloísa Buarque de. Impressões de viagem: CPC, vanguarda e desbunde: 1960/70. São Paulo: Brasiliense, 1980.

7. NAPOLITANO, Marcos. Síncope das Idéias: a questão da tradição na música popular brasileira. [S.1.]: Editora Fundação, Perseru Abramo, 2007.

8. SARAIVA, Antonio José. História da Literatura Portuguesa. Porto Editora.

9. TATIT, Luiz. O século da canção. Cotia: Ateliê Editorial, 2004. 10. TINHORÃO, José Ramos. Música popular - um tema em debate. São Paulo: Editora 34, 1997.

11. WISNIK, José Miguel. "Machado maxixe. O caso Pestana." In Teresa, no 4/5. São Paulo: Editora 34, 2003.

12. WISNIK, José Miguel. Sem receita: ensaios e canções. São Paulo: PubliFolha, 2004.

13. www.dicionariompb.com.br 